\title{
TO BELIEVE IN THE OLD CHURCH SLAVONIC GOSPEL TRANSLATION (CODEX MARIANUS) ${ }^{1}$
}

\author{
Thomas Daiber \\ The Justus Liebig University of Giessen, Giessen, Germany
}

\begin{abstract}
Drawing on theoretical definition of a speech act, the paper seeks to compare the theoretical semantics of BELIEVE with the lexical semantics of the words used in the Old Slavonic Gospel translation for expressing different modes of believing. The general principles in the use of the verb в paraphrasing utterances in comparison to Greek according to the majority of instances have been considered. The historical use of lexical material shows that the development of different ways of morphosyntactic use reflects the development of communication practices which are an index of societal behaviour. The author states it that the comparison of the speech act BELIEVE with contested lexical semantics provided the conclusion that a verb *verriti cannot be reconstructed for Proto-Slavic, but at the period under analysis the concept BELIEVE was verbalized by в ъровати with the primary personal meaning of "believe in someone" (the dative of a person is needed in constructions like "I have faith in Him"). It is supposed that the necessity to introduce the verb *verriti appeared when people started to extend the personal meaning of BELIEVE upto "an impersonal believed object" (sematic bleaching), and if they did it the verb *verriti might had been analogically produced as derivation of the primary noun. The author concludes that the translation technique of the first Slavonic Bible is more ad sensum than ad verbum and sometimes even reveals theological considerations of the translator.

The speech act BELIEVE seems to display semantic bleaching as it loses its transcendent truth conditions and becomes more and more connected with impersonal believed objects.

Key words: speech act, morphosyntactic, semantic bleaching, translation technique, Old Church Slavonic.

Citation. Daiber Th. To Believe in the Old Church Slavonic Gospel Translation (Codex Marianus). Vestnik Volgogradskogo gosudarstvennogo universiteta. Seriya 2. Yazykoznanie [Science Journal of Volgograd State University. Linguistics], 2019, vol. 18, no. 4, pp. 29-40. DOI: https://doi.org/10.15688/jvolsu2.2019.4.3
\end{abstract}

\section{ПОНЯТИЕ «ВЕРИТЬ» В ПЕРЕВОДЕ ЕВАНГЕЛИЯ НА ЦЕРКОВНОСЛАВЯНСКИЙ ЯЗЫК (МАРИИНСКОЕ ЕВАНГЕЛИЕ) ${ }^{1}$}

\author{
Томас Дайбер \\ Гиссенский университет им. Юстуса Либиха, г. Гиссен, Германия
}

\begin{abstract}
Аннотация. В статье представлены результаты сравнения содержания понятия «Верить» с семантикой слов, которые использовались в переводах Евангелия на церковнославянский язык для передачи разных признаков и характеристик веры. Проанализированы общие аспекты использования глагольной словоформы в ъровати и близкие по смыслу перифрастические высказывания в сравнении с текстом на греческом. Лексический анализ исторических источников позволил предположить, что формирование разных способов орфосинтаксического выражения указанного понятия проходило под воздействием потребностей дискур作 ния». Уточнение приемов передачи речевого акта «Верить» с помощью контекстуальной семантики слов . привело к заключению о том, что глагол *verity не может быть реконструирован как элемент протославянского, однако текстовый материал показывает, что понятие «Верить» постепенно получало выражение в формах глагола в tровати с первичным значением “верить в кого-то” (Дат. п. для лица в синтаксической конст-
\end{abstract}


рукции «Я верую в Него»). Сделан вывод о том, что потребность во введении форм глагола от *verity появилась, когда люди осознали необходимость трансформации личностного мнения на обезличенный объект (sematic bleaching), что привело к появлению аналогового деривата от именной основы. В заключении утверждается, что техники перевода текста Евангелия на церковнославянский опираются в большей степени на принцип ad sensum (приблизительно), чем на принцип ad verbum (точно).

Ключевые слова: речевой акт, морфосинтаксические особенности, размывание смысла, техника перевода, церковнославянский язык.

Цитирование. Дайбер Т. Понятие «Верить» в переводе Евангелия на церковнославянский язык (Мариинское Евангелие) // Вестник Волгоградского государственного университета. Серия 2, Языкознание. - 2019. Т. 18, № 4. - С. 29-40. - (На англ. яз.). - DOI: https://doi.org/10.15688/jvolsu2.2019.4.3

\section{Semantic properties: credibility and probability}

The semantic core of the verb "to believe" can be analysed by considering its use in specialized communication like theological literature or, quite differently, in documents of everyday speech. According to the material chosen, the results of the analysis will be different at first. While in theological literature the meaning of "to believe" or "to have belief" ultimately is connected with God's mercy to allow appropriate notions of Him and, accordingly, the speech act is connected with transcendent truth conditions, on the contrary in everyday speech "to believe" is related to epistemically more trivial phenomena ("I believe, she forgot the key") and is rather used as introduction to a declarative speech act, which adds a modal shade to the statement. "To believe" in everyday speech means that a speaker has a reason to evaluate a certain situation or event to happen most probably related to either existence (in the above mentioned example: "I believe, we will have no key") or credibility ("I believe, she is lying in saying that she's got the key") or behaviour ("I believe, she is unobservant [as always]").

We will call the object, which is evaluated by the speech act BELIEVE the "believed object". In the above mentioned example, the believed object, first of all, is "she", her possible temporal ("lying") or general ("unobservant") inherent attributes and secondly, also the future situation ("no key") resulting from the believed general or temporal behaviour of "her". The slight difference between the evaluation of inherent attributes of a person and the evaluation of situations as a result of a person's behaviour is key to understanding the variable use of "to believe". BELIEVE in a personal meaning evaluates the trustworthiness of an actor, while
BELIEVE in an impersonal meaning evaluates the probability of the occurrence of an event resp. of a situation as the outcome of someone's actions, and so, finally, in impersonal use BELIEVE evaluates the probability of phenomena that is completely unrelated to any actor's intention ("I believe it will rain"). The speech act BELIEVE seems to display semantic bleaching as it loses its transcendent truth conditions and becomes more and more connected with impersonal believed objects. The proposition "to believe in God" cannot fully be paraphrased, even not by the proposition "to trust in God", because the latter implies the existence of God and so is based on "believe" in His existence. The analogical transfer of BELIEVE from a believed transcendent to a human actor already loses the implicit confession of the actor's existence and becomes synonymous with "to trust", and the further analogical expansion to all kind of phenomena unrelated to their possible intentional production makes BELIEVE equivalent to a modal verb like "to assure". The semantic bleaching of BELIEVE seems to be a "property-type shift" [Borschev et al., 2010, p. 19] from a declarative speech act to a modal verb, but the loss of specific aspects from a conceptual point of view (like transcendent truth conditions) is probably compensated by semantic increase from a pragmatic point of view. There is a difference in saying "I assure she forgot the key" or "I believe she forgot the key". On a logical scale both propositions declare high probability of an expected event, but on a pragmatic scale the propositions may differ according to the degree the speaker draws on more or less personal information and additionally connotes a personal stance towards the event. The difference between conceptual and pragmatic semantics is not considered here. The introductory overview just illustrates the intuitive assumption, that BELIEVE 
originated as a declarative speech act which implies the notion of the existence of a transcendental actor and his inherent attributes, developing to a speech act ${ }^{2}$ which evaluates the inherent attributes of all kind of actors until it expanded in evaluating the validity of all kind of perceptions.

The "property-type shift" that turns the declarative BELIEVE to modal BELIEVE, is crossing the difference between personal and impersonal use. In evaluating the inherent attributes related to the behaviour of a believed object, the personal use of BELIEVE coincide in theological considerations and in everyday speech, because both, theological and everyday speech utterances evaluate the credibility and behaviour of a personal believed object. Such evaluation relies on the assumption, that the believed object is principally able to vary its behaviour, which for the sake of shortness shall be called "(free) will" 3 . The change in the behaviour of the believed object may not be unrelated to a general rule, and this general rule may be known to the speaker, too, but "to believe" instead of "to know" gives an assertion the modal shading of "high probability" and adds to the epistemic knowledge about a believed object the knowledge that the believed object may change its behaviour within a spectre of some behavioural possibilities. In other words: To believe in the credibility of a believed object evaluates primarily its behaviour which typically is needed if the believed object is an instance of the class "transcendent, human or (to not be offending to any pet holders) animal ${ }^{4}$ actor". In the case of believing in a transcendental actor (according to the personal concept in Christian theology) like God, theological considerations and everyday speech only differ among themselves as to which extent the existence and the behaviour of the believed object is evaluated on a modal scale towards the pole "necessity". BELIEVE in a theological sense evaluates the believed object as necessarily existing and necessarily, according to either self-revealed or logically attributed properties, exhibiting a certain behaviour (Malachi 3:6, Jak 1:17, Rm 9:11), while in everyday speech "believing in God" can be used more or less as an assertion of His possible behavioural characteristics. Because inherent properties of an actor are not visible, the believe in the possible behaviour of an actor is based on the perception of his / her usual behaviour, and so, the shift from personal to impersonal use of BELIEVE, that is the shift from a declarative ("I believe in God", "I believe she loves me") to a modal verb ("I believe it will rain"), is just substituting the concept of intentional or usual behaviour as the causal reason for some event by assuming causality as the trigger for some event. Looking for a definition of BELIEVE which combines both personal and impersonal use would summarily draw together the semantics of BELIEVE as an expression of a mental state:

(1) BELIEVE (pers / impers) = asserting truth to perceptions of a believed object and their behavioural / factual consequences with a degree of high probability.

The speech act BELIEVE either is related to a person and evaluates the other's probable behaviour, or BELIEVE is related to all kind of phenomena and evaluates the probable accuracy of the perceiver's conclusions which makes a difference in the truth conditions ${ }^{5}$. A failed BELIEVE in personal use can be caused by deception, but in impersonal use must be caused by delusion:

(2a) personal meaning: evaluating the inherent possible behaviour of another intentionally deciding actor

(2b) modal meaning: evaluating the accuracy of inherent perceptions of the perceiver

\section{Morphosyntactic properties: accusative and dative objects}

The universal semantic elements of BELIEVE (see sentence 1) always seem to occur in the act of believing, be it in personal (2a) or impersonal ( $2 b$ ) use. But how is the act verbalized and how do case roles, typically attached to the verb "believe", add to the explanation of BELIEVE as a speech act?

When a speaker is asked, why he or she believes in something, be it a personal or impersonal believed object, the answer will typically point to one or more perceptions, the speaker has made, which appear to be a sufficient base to conclude that a certain phenomenon is or will be existent or a certain event is or will be occurring. The act of believing as "asserting truth to perceptions" obviously can only be based on 
perceptions made in the past or in the present. Apart from generic utterances ("I will always believe in you", so often heard in popular lyrics) in a more factual sense, the future tense can only be used in hypothetical constructions, which set the believed object in relation to possible perceptions in the future like "if there will be dark clouds in the sky, than I will be ready to believe that it will rain". Believing is not producing the believed object, it is not a causative verb (it would be another story if "to love", which probably includes "to believe", is more causative oriented). Accusative arguments in believe-constructions seem to appear dominantly as an anaphoric or cataphoric pro-form like in the phrase " $\mathrm{He}$ believed that" which is referring a statement ("He was told, that it rains. He believed that"). There may be instances where the function of pro-forms is taken over by nouns which on their part designate separate statements ("She believed the word/ the saying") and there seem to be language specific restrictions on how many pro-forms can appear in believe-constructions. German tolerates the dative of the person and at the same time a noun in accusative case as pro-form for a separate statement ("Ihr Mann glaubt ihr [Dat] ihre Unschuld [Akk]" ${ }^{6}$ ) but I could not find any Russian example displaying a dative and an accusative object together with "to believe". While the NKRYa does not contain any example for верить and an immediately following noun in the accusative case, a Google search found only Он не верил этого от себя ${ }^{7}$, a somehow unique utterance which could well be a Germanism "er glaubte das nicht von sich". Additionally, the considerations of Metropolitan Platon (Levšin 1737-1812) about "to believe + accusative" can be quoted, however, it is not free from the influence of a foreign language. Metropolitan Platon in his $8^{\text {th }}$ Katechesis ${ }^{8}$ discusses that the Russian language displays three possibilities to connect the verb "believe" with an object (верую в Бога, верую Богу, верую Бога) but the third construction would only be used in asserting the existence of God in sentences like верую Бога быть, which clearly is a calque from the Latin accusativus cum infinitivo (credo Deum esse).

It is not trivial to ask which case roles can be constructed with "to believe". The dative case, which marks the believed object in sentences like “Она никогда не люет, я ей и так верю, а это вот вы все хотите, чтобы я ей не верила" (Николай Семенович Лесков), seems evident because, as it has been stated above, the concept of believing evaluates the possible behaviour of living beings rather than lifeless phenomena. To say "I believe in the clouds, that, if they become darker, it will rain" surely is a metaphor, turning clouds in some intentional acting beings. The sentence "I believe, it will rain (based on my perception of dark clouds)" does not evaluate the behaviour of physical objects which cannot behave outside physical laws; the only thing which can be evaluated on a scale between possibility and necessity is the point in time, when the believed event actually will occur. "I believe it will rain" evaluates the validity of the perceiver's conclusion that the necessary chain of reaction will happen in short time. In a strict sense, the "believed object" in the modal use of "to believe" is not the phenomenon, which is evaluated, any more, but the speaker himself. "I believe, it will rain", is not belief in rain, but belief in the validity of my perception, and "I believe" can be replaced with "If I am not mistaken ...".

Using "to believe" in everyday speech related to physical phenomena means to use the verb "believe" as a modal verb. The sentence "I believe it will (soon) be raining" can be replaced by "I assume, that it will (soon) be raining" and "it should soon be raining" 9 . But the sentence "I believe, God is Love" does not mean "God should be love", and the sentence "I believe in you" does not say "You should be". "To believe", if not used as a modal in everyday speech, can hardly be replaced by other expressions, at least not in its use related to religious practices. Pie. etymology has tried to connect some ie. stems for "to believe" with the lexical meaning of "heart" as if "to believe" were the metaphorical expression "to place heart in someone" in the sense "to place trust in someone". Etymologically, the connection of verbs of believing to the lexeme "heart" is not very clear [Mallory, Adams, 1991, p. 61], and at least the Slavic lexemes do not go back to a stem with the meaning "heart". According to etymological dictionaries (SYaSS, 1958, 1, p. 378; Vasmer, 1986,1, p. 292) OCS verriti is said to be a denominal derivation from věra (Vasmer, 1986, p. 299), which itself is compared to ie. nouns with the meaning "treaty" or "vow", which are 
ultimately connected with a verb stem "offer kindliness" ("Freundlichkeit erweisen", Pokorny, 1959, 3, col. 1165; reconstruction with laryngals in Derksen, 2008, p. 520). A possible verbal cognate, an antonym, namely Russian vrju "to lie" (<* vbrati; cf. Pokorny, 1959, 3, col. 1162, quoting the first edition of Vasmer), should be regarded as a special Russian development which cannot be associated directly with a pie. stem (Trubačev in Vasmer, 1986, 1, p. 361). However, in several Slavic languages věriti "believe" takes on the meaning "to curse" or "to vow" [Tolstaya, 2015], which makes a proto-Slavic verbum dicendi with the meaning "assert truth to a perception" not fully unimaginable. And it is tempting to compare OCS verra "belief" = "the result of having asserted truth to perceptions" to the perfect stem pie. *ueid- "to see" [Fortson, 2004, p. 94] and its perfect "having seen" = "to know" (cf. OCS věděti with primary present tense věmb, věsi, věstr). But while we have to leave etymological considerations to specialists, it is quite remarkable that according to present research Proto-Slavic * věriti did not exist and only the noun *verra can be found.

It is somehow counterintuitive to the general assumption and also to archaeological findings, that, while religious practices seem to always have been part of human life, Proto-Slavic did not have a verb for the existential state of mind which goes along with them. On the other hand, the contested old noun *verra is compatible with dative constructions ${ }^{10}$ as they are also found with the (later) verbs věriti / verrovati. The syntactical scheme can be constructed as

(3) case roles generally: A subject in nominative case has something in accusative case for a beneficent in dative case instantiation BELIEVE specifically: I have / имж belief / в врж in you / тебь (and your possible behaviour).

\section{Tense: personal and modal}

If the considerations summed up from (1) to (3) are true, it can be intuitively concluded that the personal meaning has evolved prior in comparison to the impersonal / modal meaning. It seems much easier to explain the development of the modal meaning as a derivation from the personal meaning than vice versa. The semantic change from personal to modal meaning as caused by introducing new objects into an existing syntactic structure is well known from other constructions. The invariantly preferred dative case role in constructions with "to believe" also seems to support the primacy of the personal meaning ${ }^{11}$. But again, it is puzzling to not have a verbal trace of *veriti in Proto-Slavic.

While BELIEF (in personal or modal meaning) is an evaluation of a phenomenon, it is rather the result of evaluation than the act of evaluating itself. BELIEVE is not an inchoative or incrementing action, but the result of "having asserted truth to perceptions". This does, of course, not affect the notion, that someone in the course of times may repeatedly and with different degrees of probability assert "truth to perceptions", which may be expressed in theological literature as becoming "firm or weak in faith". BELIEVE is always the result of asserting truth to perceptions, or, in other words, "to believe" is the result of an action. Already Vendler's classification [1957, p. 150] puts "believe" as a typical instance into the class of "stative verbs", which includes cumulativeness [Rothstein, 2008, p. 14]. This means that the intensity of believing may change according to the modal continuum between slight possibility and strict necessity, by which the perceptions are evaluated, but the state of mind "belief" does not entail different actions, the state of mind always results from evaluation of inherent, not objectively demonstrable phenomena.

Because the concept of believing is the static result of having asserted truth to perceptions it is not unexpected that "resultativity" is most prominently connected with the use of the verbs verriti / verrovati in OCS. The Gospel translation, as extend in Codex Marianus (CM; ed. Jagič $1883=1960$, digital version Lindstedt 1986), exclusively - this is apart from periphrastic constructions like "have faith" - exhibits the use of verrovati, while verriti seldom occurs in OCS literature, at all (SYaSS 1, p. 378). Only the imperfective form verrovati is frequent in OCS; its suffix $-v a$ - points to the meaning of iteration or repetition, which is consistent with the expected semantic behaviour of "cumulativeness" (see above). Other properties of OCS verrovati in comparison with the Greek source additionally show that the verb "to believe" in OCS was carefully used in respect to its resultative, stative aktionsart. 


\section{Results}

It is not the goal of this paper to analyse all translational decisions in OCS related to BELIEVE, but to outline the general principles in the use of в жровати and related paraphrasing utterances in comparison to Greek according to the majority of instances.

\section{$\pi \mathbf{\tau} \tau \varepsilon v ́ \varepsilon \mathbf{~ - ~ в ~ t р о в а т и ~}$}

In $\mathrm{CM}$ věrovati occurs 83 time, 66 tokens thereof are found in the Gospel of John. In all instances OCS verrovati are translated forms from the paradigm of Greek $\pi \imath \tau \tau \varepsilon v \varepsilon \varepsilon v$ with one exception of John 3:36, where in the Greek Gospel $\dot{\alpha} \pi \varepsilon \imath \theta \tilde{\omega} v$ (3rd person singular active present participle from 'to [not] obey') is read, but CM has 3rd person plural indicative present tense в вроуоуть. In the light of the otherwise very close translation technique of $\mathrm{CM}$, this aberrant wording may be an error or a trace of some exclusive (although eventually unknown) reading variant in the Greek manuscripts ${ }^{12}$.

The remaining 82 instances where Greek $\pi \imath \sigma \tau \varepsilon v \varepsilon \varepsilon v$ is translated by OCS в вровати саn be divided into finite (52) and infinite (4) verb forms and participles (26).

Amongst the finite verb forms, 49 Greek verb forms in indicative and 3 Greek verb forms in subjunctive had to be translated.

In indicative mood, a Greek aorist occurred 17 times and was translated by OCS

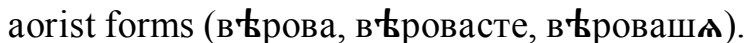
1 time (John $3: 12)$ a future tense $(\pi 1 \sigma \tau \varepsilon v ́ \sigma \varepsilon \tau \varepsilon$ $2^{\text {nd }}$ plural indicative active) was rendered by present tense (в-ьроуоуте), the other 19 present tense forms in CM (в 中роуњ, в в њроуемъ, в вроуоуте (John 3:12, 6:36, 10:25, 10:26, 16:31) and в вроуите (Mark 11:24, two times John 14:1) and в 'tроуета (Dual, Matt 9:21),

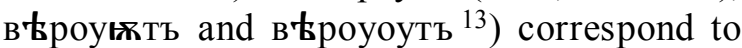
Greek present tense. 5 perfect tense forms in Greek were translated twice by imperfect tense (в ъровахъ, в њровахомъ) and 3 times by aorist forms (в врова, в вровасте). A Greek imperfect of $\pi 1 \sigma \tau \varepsilon v \varepsilon \varepsilon v$ occurs 3 times (always $3^{\text {rd }}$ person plural) and each time it was translated by OCS imperfect в вроваахж / в вровахж. 4 imperatives in Greek, one of them an imperative aorist (Luke 8:50), are all translated by OCS imperatives (в'вроуи, в вроуите).

In subjunctive mood, $\pi \_\sigma \tau \varepsilon v ́ \eta \tau \varepsilon$ ( $2^{\text {nd }}$ plural present tense) was once translated by a $d a$ - construction (John 6: 29 да в'кроуоуте), two other instances, both subjunctive aorist, were translated by present tense indicative mood. As none of the Greek subjunctive constructions involves an expression of unreality, rendering Greek subjunctive mood by OCS present tense is the expected behaviour [Daiber, 2012ab].

Four Greek infinitives of $\pi \imath \sigma \tau \varepsilon v i \varepsilon เ v, 2$ present tense, 2 aorist tense, were uniformly translated with в вровати.

Concerning the participles, all 22 present tense participles in CM conform with their Greek counterparts. 1 Greek perfect participle (John 8:31,

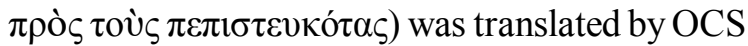
preterite participle (къ в ьровавъшиимъ) as was 1 of the 3 Greek aoristic participles (John 20:29, $\pi \_\tau \varepsilon v ́ \sigma \alpha \nu \tau \varepsilon \varsigma$ - въровавьшеи), while the other two were translated by OCS present tense participles (Mark 16:17, John 7:39).

Summarizing the translational equivalents

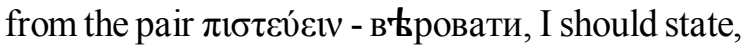
that the OCS translator is trying to keep very closely to the Greek morphosyntax. Only where no OCS equivalents existed (in the case of Greek aorist participles, aorist infinitives), the translator had to make a choice. In the case of perfect tense translation, it is obvious that the translator had chosen OCS imperfect as equivalent tense when the action of believing is conceptualized as a durative state of mind like in John 6:67-69, when apostle Peter expresses that the disciples already long ago had come to faith and now are believers:

Рече же Исусъ обњма на деслте: “еда и вы хоштете ити?" отьв Һшта емоу симонъ петрь: "Господи ... мы в ъровахомъ и познахомъ, Њко ты еси Христось, Сынъ Бога живааго"14.

When the context refers to a concrete historic event, either by negation ('you did not believe at that time') or by causal connection to other events ('then, as you saw me, you believed'), the aorist is used like in John 16:27, where Jesus refers to the fact that the disciples are believers:

самъ бо отецъ любить вы, фко вы мене възлюбисте ї в њровасте њко азъ отъ Бога изидъ.

The OCS translator had to decide whether in a given context the resultative aktionsart of perfect tense or the preterite finished action is focused by the meaning of the utterance. 
According to the criterion, he either chose imperfect as equivalent for the durative resultativity of gr. perfect tense or aorist as equivalent for the perfectivity of finished actions in preterite.

The decisions by the translator are the more remarkable, as they show that the translator is not mechanically acting; he would have been able, after all, to produce an OCS perfect tense and very schematically translate the Greek text in morphosyntactic identity. But the rise of the Slavic periphrastic perfect is connected with the decline of the synthetic preterite; the Slavic periphrastic perfect, the more it came in use, the more it differed semantically from the old analytical perfect (like 'to sit' = 'having sat down' [Aitzetmüller, 1991, S. 194 and conseq.] because its use is crucially connected with the development of the Slavic verbal aspect (see [Kerschbaumer, 1993]. This cannot be discussed here, but it is just to be observed, that the OCS translator not only resigns from translating the Greek original in morphosyntactic identity, but also shows that his distribution of imperfect and aorist tenses is context sensitively done (Table 1).

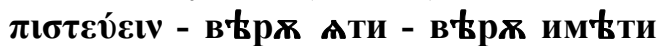

The OCS translator did not choose a finite form of věrovati every time $\pi 1 \sigma \tau \varepsilon v ́ \varepsilon v$ occurred in the Gospel. In many places, the finite forms of Greek $\pi \iota \sigma \tau \varepsilon v ́ \varepsilon \imath v$ were translated by periphrastic constructions. Apart from the optative $d a$ construction, the synthetic constructions vary between в врд Ати "to take up faith, to come to faith", в врж имати "taking faith" and вtрж им'ти "to have faith". The English equivalents are just a sketchy approximation to understand translations like (Table 2).

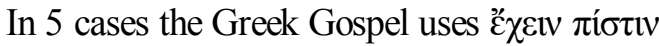
"to have faith" (Mt 17:20, 21:21, Mark 11:22, Luke $4: 44^{16}$ and 17:6), 4 times they are translated into OCS by using iméti (věro), one time by using jęti (verro). These instances will add to our interpretation, but phrases of the kind "to be faithful" (e.g. Luke 17:11, John 20:27) are left out of consideration because they don't belong to a verbal concept of "to come to resp. to have (faith)".

There are the 55 variants, where a Greek form of $\pi 1 \sigma \tau \varepsilon v \varepsilon \varepsilon 1 v$ was translated not by a synthetic form of verrovati, but by a periphrastic construction:

- 1 Greek infinitive aorist was translated by věrojęti

- 4 times a Greek imperfect tense was translated either by véro iméti (2 instances) or věro jęti

Table 1

Comparison of morphosyntactic ways to express the concept «BELIEVE»

\begin{tabular}{|c|c|c|c|}
\hline John's gospel & Greek perfect & $\begin{array}{l}\text { OCS imperfect } \\
=\text { resultative state of affair }\end{array}$ & $\begin{array}{c}\text { OCS aorist } \\
=\text { perfectivity of action } \\
\end{array}$ \\
\hline John 6:69 & $\begin{array}{l}\pi \varepsilon \pi \imath \sigma \tau \varepsilon v ́ \kappa \alpha \mu \varepsilon v- \\
1 \text { Plural Indicative Perfect }\end{array}$ & в Њровахомъ & \\
\hline John 11:27 & $\begin{array}{l}\pi \varepsilon \pi i ́ \sigma \tau \varepsilon v \kappa \alpha- \\
\text { 1Singular Indicative Perfect }\end{array}$ & в қровахъ & \\
\hline John 3:18 & 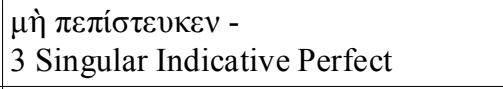 & & не върова \\
\hline John 16:27 & $\begin{array}{l}\pi \varepsilon \pi \imath \sigma \tau \varepsilon v ́ \kappa \alpha \tau \varepsilon \text { ö } \tau \imath- \\
2 \text { Plural Indicative Perfect }\end{array}$ & & в ъровасте Њко \\
\hline John 20:29 & $\begin{array}{l}\text { “O } \tau \iota \varepsilon \dot{\varepsilon} \rho \alpha \alpha \alpha \alpha_{\varsigma} \mu \varepsilon \pi \varepsilon \pi i ́ \sigma \tau \varepsilon v \kappa \alpha \varsigma \text { - } \\
2 \text { Singular Indicative Perfect Active }\end{array}$ & & Њко видЊвъ ма в њрова \\
\hline
\end{tabular}

Table 2

Comparison of syntactic constructions that represent the concept "BELIEVE"

\begin{tabular}{|c|c|c|}
\hline John's gospel & Greek - Byzantine Majority & $\mathrm{CM}$ \\
\hline John 10:38 & 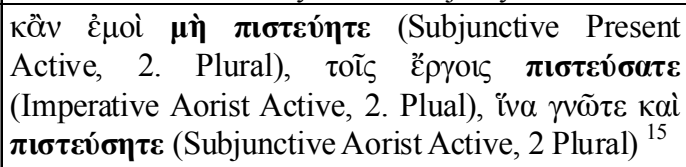 & 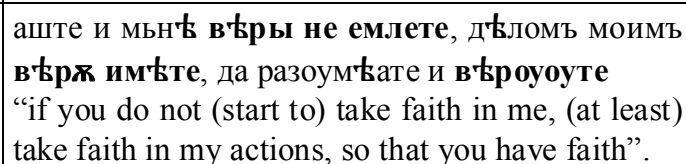 \\
\hline
\end{tabular}


(1 instance, see in the following) and also by a context sensitive deviant construction (John 2:24: не въдааше себе въ в Һрд ихъ) which is left out in our analyse.

- 5 Greek participles were rendered by věrojęti (3) or věro imati (2)

- 5 times a Greek indicative future tense was translated by the construction věro jęti (4) or věro imati (1)

- 6 times a Greek imperative form was translated by věrogjęti (4) or věro̧ imati (2)

- 6 times Greek present tense forms were translated by věro imati (5) or věro jęti (1)

- 10 times a Greek indicative aorist tense was translated by the construction vero jęti (9) or věro imati (1)

- 18 times Greek subjunctive forms were translated by věro imati (2) or věrojęti $\left(15\right.$ or $\left.16^{17}\right)$

Considering the numerical proportions, it is obvious that в врж Ати / věro jęti is primarily chosen as periphrastic OCS equivalent for all kind of synthetic Greek verb forms of $\pi 1 \sigma \tau \varepsilon v ́ \varepsilon v$. In the majority of cases the periphrastic translation verro jęti was used as equivalent to Greek subjunctive. This is expected behaviour in regard to the special aktionsart of "to believe". As was said above, "to believe" is the result of "having asserted truth to perceptions", which makes "to believe" a stative verb expressing the result of a forgoing perception. Dependent on context the durative resultativity of "to believe" either can be underlined by choosing a durative verb form "(was) believing" (like OCS imperfect for Greek perfect tense) or by choosing an aorist "believed" for stressing the perfectivity of the forgoing perception (like OCS aorist for Greek perfect tense). The inchoative or incremental action "perceiving and beginning to assert truth to perceptions" = "coming to faith" or "starting to believe", could not be expressed by using OCS verrovati, even not with the help of syntactic marking like in other languages ${ }^{18}$. The inchoative "coming to faith" is not really believing, it is just starting to believe, and this is why the expression occurs mostly in hypothetical sentences which have subjunctive mood in Greek. So, if the inchoative meaning "taking up believe" had to be expressed, в ьровати шаs replaced by a periphrastic construction. Examples for inchoative meaning of the periphrastic construction are numerous and sometimes may reveal a certain exegetical view of the OCS translator like Mt 21:32: приде бо иоанъ Крститель пжтемь праведъ-

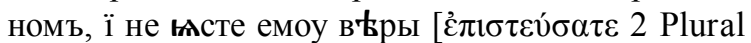
Indicative Aorist active], мытаре же и любодњицА

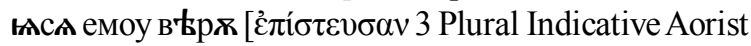
active].

In Mt 21:31 the OCS translator, guided by his subjective interpretation of the scene, wanted to conceptualize the argument that the righteous did not come to faith even by the example of John the Forerunner. This is clearly a personal decision of the translator. Instead of stressing the inchoative meaning of the process by using věrojęti, a simple aorist of в вровати would have been possible, as well, as shows Mark 11:31:

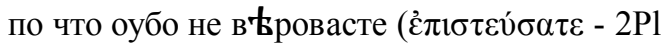
Ind Aor) емоу

where (quasi synoptically) the same situation is conceptualized: people did not believe even by the example of John the Forerunner. The comparison of Mt 21:32 with Mark 11:31 shows that in a context without explicit temporal markers there is no grammatical necessity to use either a synthetic aorist or a periphrastic construction but it is rather the subjective interpretation of the translator to choose between both possibilities.

It is clear that the use of a periphrastic construction "taking up faith" has something to do with inchoative force which is not present in the verb "to believe / verrovati", but the parallel Mt 21:32 and Mk 11:31 shows that it has no sense to compare all instances of OCS periphrastic constructions with their Greek counterparts, because this would only be an interpretation of the translator's exegetical decisions, not a comparison of semantic or grammatical equivalents. Instead, we should look at somehow extraordinary instances to define the temporal meaning of the OCS periphrastic constructions.

To define the temporal meaning of vero imati it is sufficient to have a look at Luke 8:13 where both its durativity and imperfectivity is clearly seen:

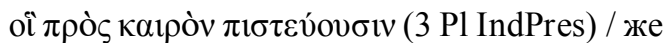
въ врЊма в врж емлють - "for a (small amount of) time take up faith"

To define the temporal meaning of vero iméti it can be contrasted with vero jęti like John 5:46: 


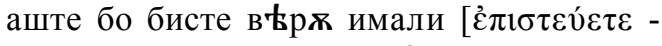
2PlIndImperfAkt] мосеови, в

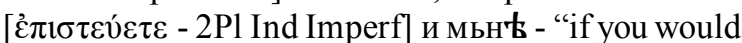
have taken faith in Moses, you would also (start to) take faith in me"

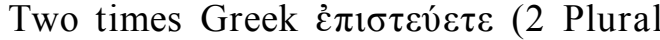
Indicative Imperfect active) had to be translated with a conditional construction. In using firstly iméti and secondly jęti, the OCS translator seems to differentiate between a temporal ground and a temporal figure. The verb iméti stresses the durativity of "having come to faith", while jęti denotes inchoativitiy and means "beginning to believe". The verb iméti in comparison to the aoristic stem jęti behaves like perfect tense "if you would have taken faith to Moses" in comparison to the actual tense, which is profiled as the figure "you would also take faith in me". Besides this temporal distinction, it should be noted that we deal with hypothetical events. This is the reason why the first iméti verro could not be expressed by verrovati, because the latter invariantly denotes a repeating perfective action "to believe", while vero iméti just means the fact "having come to faith".

Additional proof for this observation are the

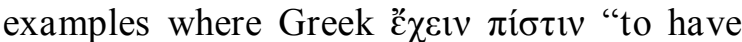
faith" was translated once by imperative form (Mk 11:22, имейте) and it occurs 3 times within a conditional sentence (аще имате, аще бисте им'лли, Mt 17: 20, Mt 21:21, Luke 17:6). The one instance (Mark 4:40) where jęti is used (чъто тако страшиви есте, како не имете в 中ры) it coordinates jeti with durative byti and again the inchoative figure is used against a durative ground: fear is the durative reason that the disciples do not even start to "take faith".

Distinguishing the 3 periphrastic constructions from the proper verb "to believe" leads to the following scheme:

- věro jęti = inchoative aktionsart, per se imperfective = "to take up faith, start believing"

- věrọ imati $=$ durative aktionsart, imperfective $=$ "having faith"

- věro iměti = durative aktionsart, finished action, but not cumulative = "to have faith" (historic event)

" věrovati $=$ durative aktionsart, finished and cumulative action $=$ "to believe" (durative situation)

This interpretation allows for understanding the periphrastic constructions in the future tense, where only the imperfective constructions with imati or jęti are used, because it would be contradictory to designate a hypothetic event (future has not yet happened) by a verb which expresses an already factual event. The same could be said about the use of jęti-constructions (and 2 times imati-constructions) in subjunctive mood which also designate hypothetical events. On the contrary, 2 of 3 Greek imperfect tenses are iméti-constructions that designate real events in preterite.

As was said above, an analysis of all instances would probably fail in distinguishing context dependent formulations or individual conceptualizations of the translator from general rules. So, we finish the overview on OCS translation of "to believe" in Codex Marianus, as it should have become clear that the translator was aware of the original semantic concept of "to believe" as a stative and cumulative verb in contrast to the verbalization of the inchoative or durative-factitive action of "coming to / having faith".

\section{Conclusion}

We started this study of "BELIEVE" in OCS, firstly, to answer a methodological question: to which extend a theoretical definition of a speech act will be supported by observable language data? The question can be eventually extended to other more complicated speech acts like "to swear". The answer, that has been retrieved by comparing the theoretical semantics of BELIEVE with the lexical semantics of the words used for expressing different modes of believing, is positive.

Secondly, comparing the speech act BELIEVE with contested lexical semantics may provide for an explanation why a verb *vériti cannot be reconstructed for Proto-Slavic. The more the primary personal meaning of "believe in someone" is the only possible concept connected with BELIEVE, the more you need the dative of a person as the believed object in constructions like "I have faith in Him". This does not solve, however, the problem if the verb *verriti became necessary when people started to extend the personal meaning of BELIEVE to impersonal meaning ${ }^{19}$, or if they did it, on the contrary, because a verb *vériti had been analogically produced as derivation of the primary noun. As 
for our time (compare the frequency of the word "God" in sentences like "Oh my God") also for historical times it is problematically to conclude from the existence of lexical material to the salience of appropriating mental concepts. The only way to elaborate on historical thinking by using lingual material is to elaborate the historical use of lexical material because the development of different ways of morphosyntactic use reflects the development of communicational practices and these are, for sure, an index of societal behaviour, too.

Thirdly, the article contributes to the notion that the translation technique of the first Slavonic Bible is more ad sensum than ad verbum and sometimes even reveals theological considerations of the translator.

\section{NOTES}

${ }^{1}$ A first draft of this paper was delivered in May 2018 during a workshop of the project "Die Ukraine: Überlappungsregion und Normexport in der Kulturwissenschaft" as part of the Giessen research cluster "Conflict Regions in Eastern Europe" within the funding program LOEWE of the Federal State Hessen (Germany), 2017-2020. I am grateful to Prof. Andriy Danylenko (New York) and Prof. Swetlana Mengel (Halle / Saale) for helpful remarks.

${ }^{2}$ Some authors state that BELIEVE is an "expressive speech act", because - according to Searle's definition - '[w]henever there is a psychological state specified in the sincerity condition, the performance of an act counts as an expression of that psychological state' (Searle, quoted in [Ronan, 2015, p. 30]). As the sincerity condition commits the speaker to the truth of his / her predication and the connected illocution, every declarative speech act involves "a psychological state" and therefor would be "expressive". Ridge [2006] is right, that sincerity is always based on the believe of the speaker that his / her state of mind is based on true perceptions and so sincerity is connected with every speech act. Only taken as a performative, like in the Credo, one could say that BELIEVE is a predication about the speaker ("I am a believer") connected with a certain illocution (either directed to God, and He will know what that means, or directed to a politically correct audience like "respect my believe, religious feelings" or the like), and so it could be called an expression of a state of mind like the expression of anger or love, e.g. But the special examples of BELIEVE as a perfomative speech act are not in the focus of Ronan [2015], which would make BELIEVE to appear as an expressive speech act in a more special sense.

${ }^{3}$ I surely have dispensed with quoting references to the philosophical problem of "free will", which is theoretically intriguing, but readily solved by a decision like to not quote literature on the problem. An introduction would be Strawson's [2008] "Freedom and Resentment" [orig. 1962].

${ }^{4}$ This would be the next philosophical question after "free will" which cannot be undertaken here. I found Pietrzykowski [2007] an interesting book on it.

${ }^{5}$ Fabiszak, Hebda, Konat [2012, p. 174] observe a difference between pol. wierzyć / uwierzyć "to believe", insofar as the aspectual imperfective partner "significantly correlates with Social Cognition indicating that shared beliefs enjoy a certain continuity and are less likely to be represented as punctual events". This difference seems analogous to the difference between personal and impersonal meaning, observed by our semantic analyses. But contrary to the Corpus Study of Fabiszak, Hebda, Konat [2012], our study distinguishes personal and impersonal use of "to believe", because not only in philosophical, but also in historical perspective the distinction can be made fruitful for older stages of language development (see 2). - The same can be said about Valentová [2003]; the rich lexical material presented there supports the distinction between personal and impersonal meaning which is necessary to explain the development of two kinds of speech acts BELIEVE (declarative and modal) as seen today.

${ }^{6} \mathrm{Can}$ be paraphrased as "Her husband believes her, when she says, that she is innocent", but is not to be mixed with "Her husband believes in her innocence" or "Her husband believes, that she is innocent", because leaving out the dative for the believed object ("her") turns "believe" into the evaluation of a perception (is she innocent?) which can be made contrarily to a possible confession of the wife (I am guilty.).

${ }^{7}$ Searched "он не верил этого" in NKRYa and Google at 13.05.2018, quotation from <http:// www.mkmusavirlik.com/userfiles/chto-pishut-naknigah-kogda-daryat-4013.xml $>$. Additional search for “а он верил то" revealed one example (“Все знали. А он верил то в одну, то в другую версию, пока маленький был") from a discussion forum $<$ https:// miumau.livejournal.com/1137647.html $>$, but the demonstrative pronoun то is rather an index ("here" and "there") than a pro-form.

${ }^{8}$ Platon (Levšin) 1781, quoted from $<$ https:// azbyka.ru/otechnik/Platon_Levshin/katehizis/8>, seen 2018, May 1 th. The same passage with same bibliographical reference appears when верую Бога is searched for in NKRYa $<$ www.ruscorpora.ru $>$ - as the only hit for the phrase.

${ }^{9}$ Note, that the should-paraphrase, contrary to the believe-sentence, needs the adverb "soon" for not acquiring a deontic reading.

${ }^{10}$ In other languages like German, the use of the personal case (dative) alternates with impersonal case (accusative) according to the criterion, if "trust in 
someone" (dative) or conviction in a fact (accusative) is to be expressed; cf. DWB 7: 7822.

11 "It is an established fact that" in all cases when a verb displays a root meaning and epistemic modal meaning, "the epistemic interpretation diachronically developed out of the non-epistemic one" [Maché, 2012, p. 110].

${ }^{12}$ I could not find the variant reading in (Aland, Nestle, 2012), but it is noted there that a group of Greek manuscripts differs from the majority reading at this place.

${ }^{13}$ John 12: 44 combines singular forms $\pi \imath \sigma \tau \varepsilon v ́ \omega v$

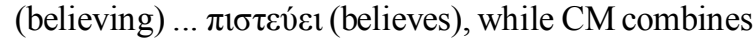
plural forms в ьроуюи ... в вроуоуть; no hint to reading variants in (Aland, Nestle, 2012).

${ }^{14}$ In quotations from OCS I dissolved abbreviations and added punctuation.

${ }^{15}$ The Western (Alexandrinian) redaction of Joh

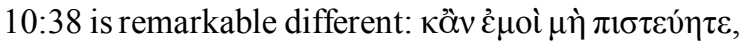

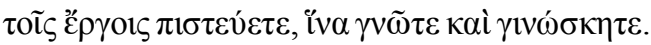

${ }^{16}$ Only in the Byzantine majority reading.

${ }^{17}$ John 11:42 reads да в ьрх имжть, which may go back to iméti as well.

18 "It is especially revealing that verbs which are standardly used in a stative / durative meaning like gilouban 'to believe' in (John 2:11, crediderunt in eum discipuli eius) receive an inchoative reading if used clause-initially" [Drinka, 2011, p. 222]; the quotation in brackets is a reference number to another page in Drinka's text; I substituted it by the reference text itself). Drinka's statement surely is true for Germanic and Romance languages (another example would be habere = "to have") but cannot be supported from a Slavonic point of view. In OCS syntactic positions vary, because inchoativity is not an inherent reading possibility of "to take faith", but its objective meaning. Regarding the whole hypotactic construction, OCS "to take faith" occurs post-positioned in $d a$-constructions (e.g. John 13:9) or relative clauses (John 8:45) and regarding the individual sentence level like John 10: 38 (аште и мьн' в 'ъры не емлете, дыломъ моимъ в extensions (мн中, даломъ) are found in initial position. In OCS the semantic notion of inchoativity is not produced by syntax, but by the lexical content of jęti "to take, be in the process of taking".

${ }^{19} \mathrm{I}$ am not sure if the development of lexical material gives the possibility to conclude from it on the mentral possibility of previous humans [Pyataeva, 1996, p. 147], although lingual material is sometimes the only material at all allowing for such research questions.

\section{REFERENCES}

Aitzetmüller R., 1991. Altbulgarische Grammatik als Einführung in die slavische Sprachwissenschaft. Freiburg im Breisgau, Weiher. X. 291 S.
Borschev V., Padučeva E.V., Partee B., Testelets Ya., Yanovich I., 2010. On Semantic Bleaching and Compositionality: Subtraction or Addition? (On the Bleaching of "Lexical Verbs" in Russian Negated Existential Sentences). Falk Ye.N., ed. Proceedings of Israel Association for Theoretical Linguistics 26, Bar Ilan University. URL: http://linguistics.huji.ac.il/IATL/26/ Borschev_Paducheva_Partee_Testelets_Yanovich.pdf (accessed 11 January 2019).

Daiber Th., 2012a. Analiticheskoe vyrazhenie optativa $\mathrm{v}$ tserkovnoslavyanskom yazyke (na materiale perevoda «Besedovnika» v «Velikikh Mineyakh Chetyikh») [Analytical Expression of the Optative in the Church Slavonic Language (Based on the Translation of Besedovnik in the Great Menaion Reader]. Uchennye zapiski Kazanskogo universiteta. Seriya "Gumanitarnye nauki", vol. 154, book 5, pp. 7-16.

Daiber Th., 2012b. Tssl. soslagatelnoe naklonenie i "negativnaya vezhlivost" (na materiale "Paterika Rimskogo"v VMCh) [Church Slavonic Language Subjunctive Mood and 'Negative Politeness' (Based on „Paterik Rimskiy“ in the Great Menaion Reader)]. Wierzbicski Ja., Tsoj A., Ginter A., Kamicska A., eds. Yazyk $i$ stil literat7urnykh i neliteraturnykh tekstov [Language and Style of Literary and NonLiterary Texts]. Lodz, pp. 7-20.

Drinka B., 2011. The Sacral Stamp of Greek: Periphrastic Constructions in New Testament Translations of Latin, Gothic, and Old Church Slavonic. Welo E., ed. Indo-European Syntax and Pragmatics: Contrastive Approaches. Oslo, pp. 41-73.

Fabiszak M., Hebda A., Konat B., 2012. Dichotomy Between Private and Public Experience: The Case of Polish Wierzycm 'Believe'. Hart Ch., ed. Selected Papers from UK-CLA Meetings 1. London, UK Cognitive Linguistics Association, pp. 164-176.

Fortson B.W., 2004. Indo-European Language and Culture: An Introduction. Oxford, Blackwell Publ., xviii. 468 p.

Kerschbaumer G.W., 1993. Die l-Periphrase in der altrussischen Version des "Jüdischen Krieges" von Josephus Flavius. Das echte und das fingierte Perfektpräsens. Freiburg im Breisgau. $227 \mathrm{~S}$.

Maché Ja., 2012. Exploring the Theory of Mind Interface. Abraham W., Leiss E., eds. Modality and Theory of Mind Elements Across Languages. Berlin, Boston, de Gruyter, pp. 109-146.

Mallory J.P., Adams D.Q., 1997. Encyclopedia of IndoEuropean Culture. London, Chicago, Fitzroy Dearborn. 829 p. 
Pietrzykowski T., 2007. Spór o prawa zwierzqt. Katowice, Sonia Draga.

Pyataeva N.V., 1996. Opyt dinamicheskogo opisaniyaa sinonimichnykh etimologicheskikh gnezd * em$\mathrm{i} *$ ber- 'brat, vzyat $\mathrm{v}$ istorii russkogo yazyka [Experience of Dynamic Description of Synonymous Etymological Nests * em-i * ber 'brat, vzyat in the History of the Russian Language]. Trubachev O.N., ed. Etimologiya 1994-1996 [Etymology. 1994-1996]. Moscow, Nauka Publ., pp. 140-147.

Ridge M., 2006. Ecumenical Expressivism: Finessing Frege. Ethics, 116, pp. 302-336.

Ronan P., 2015. Categorizing Expressive Speech Acts in the Pragmatically Annotated SPICE Ireland Corpus. ICAME Journal, no. 39, pp. 25-45.

Rothstein S., 2008. Verb Classes and Aspectual Classification. Structuring Events: A Study in the Semantics of Lexical Aspect. Chichester (West Sussex), Wiley, pp. 1-35.

Strawson P.F., 2008. Freedom and Resentment and Other Essays. London, New York, Routledge. 288 p.

Tolstaya S.M., 2015. Iz leksiki drevnego slavyanskogo prava: *klętva, *rota, *prisęga, *věra [From the Vocabulary of the Ancient Slavic Law: *klętva, *rota, *prisęga, *věra]. Berezovich E.L., ed. Etnolingvistika. Onomastika. Etimologiya [Ethnolinguistics. Onomatology. Etymology]. Yekaterinburg, Izd-vo Uralskogo universiteta, pp. 274-276.

Valentová I., 2003. Vera, zvera, viera, verung; borg; verit', zverit'; borgovat'. Slovenská reč, no. 68/3, pp. 137-149.

Vendler Z., 1957. Verbs and Times. The Philosophical Review, no. 66(2), pp. 143-160.

\section{SOURCES}

Aland B., Aland K., Karavidopoulos J., Martini C.M., Metzger B.M., 2012. Novum Testamentum Graece. Based on the Work of Eberhard and
Erwin Nestle. Stuttgart, Dt. Bibelgesellschaft. $94,890,220 \mathrm{p}$.

Jagič V., ed., 1960. Quattuor Evangeliorum versionis palaeoslovenicae Codex Marianus Glagoliticus characteribus cyrillicis transcriptum. Zuerst 1883, Nachdruck. Graz, Akademische Druck-und Verlagsanstalt, XXX. 607 p.

Lindstedt J., 1986-2010. Corpus Cyrillo-Methodianum Helsingiense. An Electronic Corpus of Old Church Slavonic Texts. URL: http://www. helsinki.fi/slaavilaiset/ccmh/.

Natsionalnyy korpus russkogo yazyka [National Corpus of the Russian Language]. URL: www.ruscorpora.ru.

Platon, mitropolit (Levshin, Petr Georgievich), 1781. Katekhizis, ili pervonachalnoe nastavlenie $v$ Christianskom zakone, kotoroe po obychayu $v$ Moskovskoy Slaveno-Greko-Latinskoy Akademii izdavna prinyatomu, preosvyashchennym Platonom, arkhiepiskopom Moskovskim $i$ Kaluzhskim $i v$ to vremya, kak on byl $v$ pomyanutoy Akademii piitiki uchitelem, vsenarodno tolkovano bylo $v$ akademicheskoy auditorii sentyabrya 1757 po 15 iyulya 1758 goda [Catechesis...]. Moscow, Senatskaya tipografiya F. Gippiusa. 374 p.

\section{DICTIONARIES}

Derksen R. Etymological Dictionary of the Slavic Inherited Lexicon. Leiden, Brill, 2008. 726 p.

Grimm Jacob and Wilhelm. Deutsches Wörterbuch. Leipzig, Hirzel, 1854-1961, 1971.

Pokorny J. Indogermanisches etymologisches. Wörterbuch. 3 Bände. Bern. Francke, 1959.

Slovnik yazyka staroslověnského. Lexicon linguae palaeoslovenicae. 5 Bände. Praha, ČSAV, 1958-2010.

Vasmer M.; Trubachev O.N., transl. Etimologicheskiy slovar russkogo yazyka: $v 4 t$. [Etymological Dictionary of the Russian Language. In 4 Vols.]. Moscow, Progress Publ., 1986-1987.

\section{Information about the Author}

Thomas Daiber, Doctor of Sciences (Philology), Professor, Slavistic Institute, The Justus Liebig University of Giessen, Ludwigstrasse, 23, 35390 Giessen, Germany, thomas.daiber@slavistik.unigiessen.de, ScopusID: 26432548300

\section{Информация об авторе}

Томас Дайбер, доктор наук (филология), профессор Института славистики, Гиссенский университет им. Юстуса Либиха, Людвигштрассе, 23, 35390 г. Гиссен, Германия, thomas.daiber@slavistik.unigiessen.de, ScopusID: 26432548300 